\title{
Idealister og realister i USAs Midtesten-politikk
}

I amerikansk utenrikspolitikk står idealistene på Israels side. Spørsmålet er hvor lenge idealismen kan styre USAs Midtøsten-politikk. Paradoksalt nok gjelder dette også hvis det idealistiske prosjektet for demokratisering av det "større Midtøsten" i en viss utstrekning lykkes. 
TEKST: Stein Tønnesson

DET ER VIKTIG ^ VARE klar over at skillet mellom idealister og realister i USA går på tvers av skillet mellom demokrater og republikanere. Tradisjonelt har demokratene hatt større hang til idealisme enn republikanerne, men nå er det blitt motsatt. En religiøst fundert idealisme har fått en sterk stilling blant de nykonservative $i$ Det republikanske partiet. Det har også vokst frem en tilsvarende idealistisk nyliberal retning hos demokratene. Samtidig har Bush-idealismen skapt en tverrpolitisk reaksjon fra realister i den amerikanske samfunnseliten. Nyttårs-nummeret av bladet Economist I. januar 2005 trykket på baksiden av forsiden en annonse med et opprop fra en såkalt "koalisjon for en realistisk utenrikspolitikk”. Den understreket at USAs to viktigste interesser i Midtøsten er å vinne den globale krigen mot Osama bin Ladens terroristiske Al Qaeda-nettverk og sikre fortsatt tilgang på olje fra Persiagulfen. På dette grunnlag tok koalisjonen til orde for å presse frem en endelig løsning på konflikten mellom Israel og palestinerne:

Det faktum at USA allment oppfattes som en støttespiller for Israels fortsatte okkupasjon av arabiske landområder - inkludert islams tredje helligste sted Jerusalem - gjør det vanskeligere for oss å få med oss alliansepartnere $i$ den globale krigen mot Al Qaeda.

De mente det var nødvendig å gi klar og tydelig støtte til opprettelsen av en uavhengig palestinsk stat. Bak koalisjonen sto en rekke av de mest kjente navnene innenfor det amerikanske akademias utenrikspolitiske ekspertise, som Richard Betts, Michael Doyle, Stanley Hoffmann, Samuel Huntington, G. John Ikenberry, Robert Jervis, Miles Kahler, Anatol Lieven, John J. Mearsheimer, Stephen Walt, Kenneth Waltz og William Wohlforth.

På bakgrunn av den amerikanske utenrikspolitiske elitens forhåpning om at Bush skulle besinne seg og slå inn på en mer realistisk utenrikspolitikk i sin andre periode, kom det som litt av en kalddusj at Bush og hans nye utenriksminister, den tidligere nasjonale sikkerhetsrådgiver Condoleezza Rice, i sine taler ved tiltredelsen i januar 2005 gikk lenger enn noen gang før i idealistisk retning. I sin tiltredelseserklæring 20. januar sa George W. Bush: "Vi ledes, av hendelser og fornuft, til én slutning: Frihetens overlevelse i vårt land avhenger $i$ økende grad av at friheten seirer i andre land. Det beste håp for fred i vår verden er at friheten spres i hele verden." På dette grunnlag definerte han det som 
USAs politikk å støtte demokratibevegelser og demokratiske institusjoner i “enhver nasjon og kultur, med det sluttmål å gjøre ende på tyranniet i vår verden”. Alle som lever i tyranni og håpløshet skulle vite at USA ikke ville ignorere deres tilstand eller unnskylde deres undertrykkere. Som Robert Kagan skrev i Washington Post den 23. januar, er dette i pakt med USAs mest revolusjonære tradisjon og utgjør "konservatismens antitese".

I talen om rikets tilstand 3. februar gikk Bush videre. Under overskriften "Seierens virkemidler” redegjorde han for hvordan

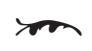

Før Bush ble valgt fremsto han med en politikk som gikk ut på å redusere USAs engasjement ute $i$ verden.

USA vil gå frem for å styrke frihetens krefter i denne krigstiden. Han nevnte nå bare så vidt "krigen mot terror", som han ellers har terpet på kontinuerlig siden II. september, men snakket til gjengjeld om en krig for frihet. Han lovet at Amerika skulle stå sammen med "frihetens allierte" for å støtte demokratibevegelser i Midtøsten så vel som andre steder, med det endemål å gjøre slutt på alt tyranni. I Midtøsten var det, sa han, i ferd med å vokse frem en bue (arc) av reform fra Marokko til Jordan og Bahrain. Palestinerne var i ferd med å reformere seg, og målet var å få to demokratiske stater, Israel og Palestina, til å leve fredelig side om side. Saudi-Arabia og Egypt skulle vise vei ved å reformere seg selv, mens det ville bli nødvendig å konfrontere Syria og Iran. Irak ville også en tid fremover fortsette å være en "vital front i krigen mot terror", og de amerikanske troppene ville bli i Irak så lenge det var nødvendig.

Condoleezza Rice kom med tilsvarende utsagn i sin tale til Kongressen da hun tiltrådte den 28. januar: "Vi streber ikke bare mot fravær av terrorisme. Vi streber mot en verden der menns og kvinners trang til frihet triumferer."

\section{Realisme på idealismens premisser}

Den utenrikspolitiske doktrinen som Bush og Rice står for, er på sett og vis en doktrinemessig nyvinning fordi den smelter sammen idealisme og realisme på idealismens premisser. Før Bush ble valgt første gang i 2000 fremsto han offentlig med en politikk som gikk ut på å redusere USAs engasjement ute i verden, og Rice var den gang utpreget realistisk i sin utenrikspolitiske tenkning. Men alt før II. september gikk tenkningen i Det hvite hus i retning av en mer aksjonistisk utenrikspolitikk, særlig i forhold til Irak.

Aksjonismen skjøt selvsagt fart etter Al Qaedas voldsdåd. Samtidig begynte Rice og hennes folk i Det nasjonale sikkerhetsråd et arbeid med å konstruere en ideologi bygget på realisme og idealisme. Dette kom til uttrykk i den nye sikkerhetsdoktrinen som ble fremlagt i september 2002. Doktrinen tok nemlig ikke bare til orde for å sikre USAs militære dominans i verden gjennom opprustning og preventiv krigføring (kalt “forkjøps-krig”), men foreslo også noe som ble kalt "maktbalanse til fordel for frihet" (power balance in favor of freedom). Maktbalanse er et typisk ord fra realistenes vokabular. Men i sikkerhetsdoktrinen ble ikke ordet brukt om forholdet mellom territorielle stater, men i stedet om forholdet mellom frihet og undertrykkelse. 
Og målet var ikke maktbalanse i betydningen likevekt. Målet for sikkerhetsdoktrinen var å sikre at det alltid er slik at frihetens vektskål veier tyngre enn diktaturets. I dokumentet ble resten av verdens stater plassert i den ene eller andre vektskål alt etter hvordan de forholder seg til frihet (Kina ble oppfattet som tvetydig). I sin tiltredelseserklæring i 2005 gikk altså George W. Bush enda lenger. Nå hevdet han at USAs nasjonale sikkerhetsinteresser kun kan ivaretas hvis frihetens krefter seirer over hele verden. Et realistisk forsvar av USAs nasjonale interesser fordrer total idealisme. Målet er å samle all vekt i frihetens skål.

I mer private budskap har Bush og Rice gitt kraftig ros til den israelske høyreorienterte politikeren og forfatteren Natan Sharansky, hvis bok «The Case for Democracy: The Power of Freedom to Overcome Tyranny \& Terror» har inspirert Det hvite hus med sin klare inndeling av verden i gode og onde krefter. Sharansky, som i sin tid var dissident i Sovjetunionen, spiller nå en viktig politisk rolle i Sharons regjering. Det er et sentralt premiss for Bush-administrasjonens midtøstpolitikk at USA - særlig under Reagan - spilte en viktig rolle i å fremprovosere de østeuropeiske diktaturenes fall. Nå vil Bush gjøre Reagan bedriften etter i Midtøsten. Det var noe av hensikten med angrepet på Irak i 2003 og danner også grunnlaget for USAs press mot Iran og Syria i dag. Det henger og nært sammen med et bredere amerikansk initiativ for et demokratisk såkalt "større Midtøsten".

\section{Initiativet for et demokratisk Midtøsten}

Et av Bush-administrasjonens håp da USA invaderte Irak i mars 2003 var å kunne

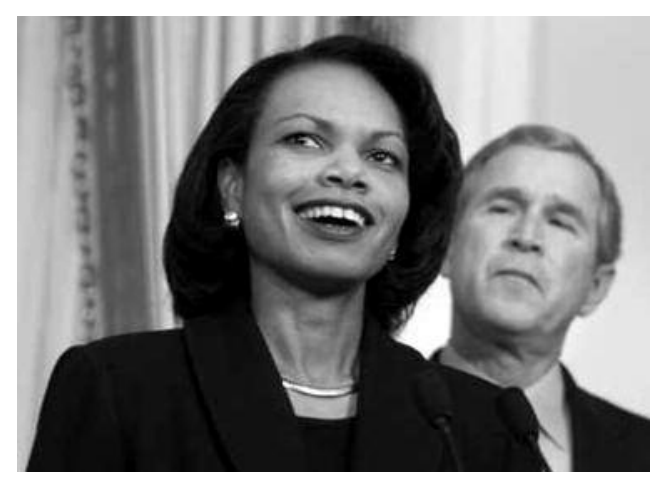

Rice og Bush sin utenrikspolitiske doktrine er en nyvinning som smelter sammen idealisme og realisme på idealismens premisser.

skape et demokratisk Irak som skulle åpne for en bølge av demokratisering i det “større Midtøsten”. Invasjonen ville skape frykt blant andre anti-vestlige regimer for sanksjoner og nye angrep, og ville derfor tvinge stater som Syria, Iran og Libya til å gjennomføre demokratiske reformer. Samtidig ville USAs tradisjonelle allierte i regionen (Saudi-Arabia, Egypt, Bahrain, De forente arabiske emirater, Kuwait og Tyrkia) bli nødt til å ta presset for demokratisering på alvor for å unngå å miste amerikansk støtte.

Disse forhåpningene fikk uttrykk $\mathrm{i}$ det som høsten 2003 ble kjent som "the Greater Middle East Initiative" og som i juni 2004, da det ble diskutert på G8-landenes toppmøte, fikk navnet "the Broader Middle East and North Africa Initiative (BMENA)". Da hadde EU allerede lenge arbeidet med støtte til styresett-reformer i Midtøsten gjennom Barcelona-prosessen. Blant de som hadde større tro på møysommelig europeisk diplomati enn amerikansk press ble det nå vanlig å snakke om "the Wider Middle East” for å unngå sammenblanding med USAs "Greater” og "Broader”. Valget av adjektiv viste hvor man sto. BMENA er et godt eksempel på et idealis- 
tisk amerikansk prosjekt som i hvert fall frem til valget i Irak i slutten av januar 2005 hadde få virkninger. De amerikanske forhåpningene om at Saddam Husseins fall og lanseringen av BMENA skulle føre til raske endringer ble nemlig gjort til skamme. Det hadde en serie viktige grunner. Den første og viktigste var opprøret i Irak mot den amerikanske okkupasjonen. Det styrket den utbredte oppfatningen blant araberne, ja for så vidt i hele den muslimske verden, om at Israel og USA utgjør en allianse rettet mot islam. Palestinernes kamp mot Israel og irakernes kamp mot USA ble av mange oppfattet som del av den samme striden. Opprøret mot det amerikanske okkupasjonsstyret i Irak fjernet mye av frykten som andre midtøstregimer følte for amerikansk press og ga dem et pusterom fra kravet om demokratisering. Isteden kunne de drive et aktivt diplomati overfor andre stater og firmaer enn de amerikanske, for å sikre seg nye allierte. Dette bidro til å svekke USAs innflytelse i regionen.

En annen grunn til at BMENA fikk så få virkninger var mangelen på aktiv oppslutning fra EU-landene, Russland, India og Kina. De uttrykte selvsagt støtte, men var egentlig lunkne. En tredje viktig grunn er at initiativet i forste omgang hoppet bukk over det som de fleste arabere oppfatter som Midtøstens politiske hovedproblem, nemlig Israels okkupasjon av palestinske områder i Gaza og på Vestbredden. Det ga aviser og intellektuelle i regionen en god grunn til å avvise BMENA og komme med motforslag. En fjerde grunn er trolig at Bush-administrasjonen, akkurat som tidligere amerikanske administrasjoner, fant at det var risikabelt å legge for sterkt press på de gjenværende regimene i
Midtøsten. En femte grunn var at BMENA ikke tok opp midtøststatenes sikkerhetsbehov. Det som i sin tid gjorde Helsinki-prosessen akseptabel for de østeuropeiske kommunistregimene, var koblingen til garantier for disse statenes sikkerhet. Hvis det samme hadde vært tilfelle for BMENA, er det mulig at de lokale regimene ville ha gjort mer for å støtte initiativet. Men Bushadministrasjonen ønsket ikke å diskutere sikkerhet på regionalt nivå, bare i tosidige samtaler med hvert enkelt stat. En sjette og siste grunn er at de målene som ble definert i BMENA var av en type som ikke kan nås raskt, men som krever en langvarig prosess.

BMENA fikk tre hovedmål: fremme demokrati og godt styresett, skape et kunnskapssamfunn, og utvide økonomiske muligheter. Innenfor hvert av disse områdene er målet dessuten å gi kvinner økt makt og beskytte deres rettigheter.

Midlene for å nå disse målene er i hovedsak hjelpeprogrammer. Slike programmer har allerede vært på plass i lengre tid med EU-finansiering, sælig gjennom den såkalte Barcelona-prosessen, som startet $i$ I995. USA brukte også 250 millioner USD på demokratiprogrammer i Midtøsten i tiåret før Bush Jr. kom til makten. Bushadministrasjonen har bevilget betydelig mer til programmet, men de viktigste endringene som er skjedd, er (a) at demokratisering av Midtøsten er blitt en deklaratorisk politikk og en del av USAs retorikk, og (b) at behovet for reform er blitt tatt opp diplomatisk med regjeringene i Midtøsten på høyeste politiske nivå. Mens den forste av disse endringene godt kan tenkes å ha vært kontraproduktiv, gitt at motviljen mot USA er så stor i regionen rent generelt, er det mulig at den andre 

endringen har hatt en viss effekt. Når krav om politisk reform knyttes til forhandlinger om våpenhjelp, våpensalg eller andre økonomiske ytelser, er det vanskelig for motparten å ignorere dem. Det ble utvilsomt lagt merke til at Bush ikke bare nevnte Syria og Iran i sin tale om rikets tilstand i februar 2005, men også nevnte behovet for reform i Saudi-Arabia og Egypt.

Det vi har sett, er at de fleste regjeringene i Midtøsten har uttalt seg positivt om behovet for "reform" og at de har gjennomført en del mindre tiltak, som skal foregi å være skritt på veien. Samtidig hevder de at mer radikale reformer $\mathrm{i}$ retning av åpenhet og respekt for menneskerettighetene kan hjelpe terroristene. Det er også blitt mer debatt i flere midtøstland om demokratispørsmålet. Selv om mange av de synspunktene som fremkommer baseres på anti-demokratiske grunnsyns-punkter med utgangspunkt i spesielle tolkninger av den islamske tradisjonen, kommer også mange prodemokratiske synspunkter til uttrykk. Noen ser demokratisering som et middel til å styrke de kreftene som bekjemper USAs imperialisme og USAs samarbeid med autoritære regimer. Et lite mindretall er også mer pro-amerikanske.

BMENAs paradoks er at i den grad det får en demokratiserende virkning, vil disse virkningene lett komme til å styrke regionens anti-amerikanske grunnholdning. Det gjør det lite fristende for EU-landene å knytte seg for sterkt til det amerikanske initiativet, selv om de sympatiserer med programmets mål og selv arbeider mer diskret i samme retning. De pro-demokratiske gruppene i Midtøsten står også overfor et kinkig dilemma: Hvordan kan de bruke de mulighetene som USAs aksjonisme skaper til å få gjennomslag for reformer - uten å bli oppfattet som USAs løpegutter?

\section{Irak-krigens virkninger}

Israel ønsket og støttet det amerikanske angrepet på Irak i 2003. Saddam Husseins regime hadde aldri sluttet fred med Israel, og Israel følte seg mer truet enn noen andre av utsiktene til at Saddam skulle utvikle masseødeleggelsesvåpen. Men de langsiktige virkningene av krigen i Irak kan lett bli negative for Israel hvis konflikten med palestinerne fortsetter. Ethvert regime i Bagdad vil støtte palestinernes kamp mot Israel, og USA må ta hensyn til Bagdad for å få beholde sine baser i landet og få fart på irakisk oljeeksport. Når USA nå ikke bare skal ta hensyn til sitt forhold til Egypt, Saudi-Arabia og Jordan, men også til Irak, blir det enda vanskeligere for Washington å overse palestinernes rettmessige krav. President Mahmoud Abbas har kanskje ikke noen stor popularitet hos palestinerne, men fra amerikansk og israelsk synsvinkel er det knapt mulig å forestille seg en mer moderat palestinsk leder enn ham. Når utenriksminister Condoleezza Rice skal sette opp en strategi for å stabilisere Midtøsten i Irakkrigens kjølvann, er det derfor ingen vei utenom å forsøke å lykkes der så mange av hennes forgjengere har feilet, nemlig å presse frem en israelskpalestinsk fredsløsning.

\section{Irak-valgets virkning}

Etter alle de feilene USA gjorde som okkupasjonsmakt i Irak var det utvilsomt en genistrek å insistere på å avholde valg i januar 2005, på tross av alle dystre spådommer. At dette valget ble så vellykt, med nesten 60 prosent valgdeltagelse, ble av Bush oppfattet som en triumf. Og det bidro 
sammen med valget på ny palestinsk president til et stemningsskifte i Midtøsten, som muligens kan fremme BMENAs mål. Når den sentrale libanesiske opposisjonspolitikeren, tidligere statsminister Hariri kort etter ble myrdet $\mathrm{i}$ et bombeattentat, bidrar det trolig også til å skjerpe kravene om demokrati i regionen og til en ytterligere skjerping av USAs politikk overfor Syria. Men om dette stemningsskiftet er varig, er høyst usikkert. For det første står Iraks nye regjering overfor en meget vanskelig oppgave med å utforme en grunnlov som kan være akseptabel for alle landets folkegrupper. For det andre kan det komme til akutt krise i USAs forhold til Iran og Syria. Og for det tredje kan den nye fredsprosessen mellom Israel og palestinerne lett kullkastes av nye voldsepisoder enten mellom palestinerne og Israel eller internt blant palestinerne. Slike utviklingstrekk kan på nytt skjerpe fiendebildet av USA. Det kan trygt sies at de nye dominerende sjiapolitikerne i Irak ikke er pro-amerikanske, og det synes i det hele tatt som om så vel regjeringer som de dominerende politiske strømningene er i ferd med å vende seg bort fra USA. Paradoksalt nok kan demokratisering bidra til å styrke denne tendensen.

\section{Veien videre}

Israel kan ikke regne med å beholde like sterk støtte fra USA i årene fremover hvis okkupasjonen av palestinske områder og den vapnede konflikten med palestinerne fortsetter. Jo større vansker USA får i Irak og jo tydeligere det blir at de arabiske regimene vender seg bort fra USA og isteden søker økonomisk og politisk samarbeid med EU-landene, Russland og Kina, jo viktigere blir det for USA å bevege seg i ret- ning av en mer realistisk midtøstpolitikk. Det innebærer støtte til opprettelsen av en levedyktig palestinsk stat. Hvis Israel ønsker å bevare sitt nære forhold til USA, vil det derfor trolig være nødvendig å gi betydelige innrømmelser til palestinerne. Tilbaketrekningen fra Gaza vil bare være en begynnelse. Det neste vil vær å bøye seg for det palestinske folkekravet om frigivelse av politiske fanger, med Marwan Barghouti i spissen. Deretter kommer forhandlingene om Vestbredden. De israelske bosetningene må rømmes. Bygninger og infrastruktur må overlates intakt til palestinerne, som må få støtte til å bygge nord-sørgående veier. Den nye muren må rives eller flyttes til grensen fra 1967 . Hvert eneste lille avvik fra I967-grensen må eventuelt forhandles frem med palestinske representanter og kompenseres for territorielt eller på annen måte. Det må finnes en kompromissløsning når det gjelder palestinernes krav om å få vende hjem til hjemstedene i Israel. Palestinerne må sikres vann og må kunne arbeide i Israel. Politisk sett arbeider tiden for palestinerne, hvis de greier å avholde seg fra bruk av terror. Selv om USA for øyeblikket er preget av en religiøs-politisk utenrikspolitisk idealisme, som går meget langt i sin støtte til Israel, vil palestinerne $\mathrm{i}$ tiden fremover kunne nå langt med en kombinasjon av ikke-voldelig mobilisering, internasjonalt diplomati og en langsiktig forhandlingsprosess med Israel. Ethvert terrorangrep fra Hamas eller andre palestinske grupper vil være en gavepakke til de i Israel som tror de kan beholde store deler av Vestbredden og til de som ønsker å ytterligere stimulere den amerikanske utenrikspolitiske aksjonismen. 